\title{
Spray volumes in the industrial treatment on the physiological quality of soybean seeds with different levels of vigor $^{1}$
}

\author{
Cristian Rafael Brzezinski2 ${ }^{*}$, Julia Abati ${ }^{2}$, Fernando Augusto Henning ${ }^{3}$, \\ Ademir Assis Henning ${ }^{3}$, José de Barros França Neto ${ }^{3}$, \\ Francisco Carlos Krzyzanowski ${ }^{3}$, Claudemir Zucareli ${ }^{2}$
}

\begin{abstract}
The aim of this work was to evaluate the effect of different spray volumes, via industrial treatment, on the physiological quality of soybean seeds with different levels of vigor. The experimental design was completely randomized in a $2 \times 5$ factor scheme, with four replications. Factors consisted in two levels of seed vigor (high and low) and five spray volumes $\left(0,600,1200,1800\right.$ and $\left.2400 \mathrm{~mL} .100 \mathrm{~kg}^{-1}\right)$. Products used to obtain the volumes were: fungicide (carbendazin + thiram); insecticide (imidacloprid + thiodicarb); nematicide (abamectin); micronutrients (cobalt, molybdenum and zinc); polymer (peridiam); biostimulants (kinetin + gibberellic acid) and inoculum (Bradyrhizobium japonicum). The used cultivars were BRS 360 RR and BRS 1010 IPRO. The physiological seed quality was determined by the following evaluations: germination, first count of the germination test, seedling emergence in sand, emergency speed index, total length of shoot and root of the seedlings. In the different spray volumes, high vigor soybean seeds have higher physiological quality than low vigor seeds. The increased spray volumes in seed treatments reduce the physiological quality of low vigor soybean seeds.
\end{abstract}

Index terms: Glycine max (L.) Merrill, fungicides, insecticides, germination, seedling emergence.

\section{Volumes de calda no tratamento industrial sobre a qualidade fisiológica de sementes de soja com diferentes níveis de vigor}

\begin{abstract}
RESUMO - O objetivo foi avaliar o efeito de diferentes volumes de calda, via tratamento industrial, sobre a qualidade fisiológica de sementes de soja com diferentes níveis de vigor. O delineamento experimental foi inteiramente casualizado, em esquema fatorial $2 \times 5$, com quatro repetições. Os fatores foram constituídos por sementes com dois níveis de vigor (alto e baixo) e cinco volumes de calda $\left(0,600,1200,1800\right.$ e $\left.2400 \mathrm{~mL} .100 \mathrm{~kg}^{-1}\right)$. Os produtos utilizados para a obtenção dos volumes foram: fungicida (carbendazin + thiram); inseticida (imidacloprido + tiodicarbe); nematicida (abamectina); micronutriente (cobalto, molibdênio e zinco); polímero (peridiam); bioestimulante (cinetina + ácido giberélico) e inoculante (Bradyrhizobium japonicum). As cultivares utilizadas foram BRS 360 RR e BRS 1010 IPRO. A qualidade fisiológica das sementes foi determinada pelas seguintes avaliações: germinação, primeira contagem do teste de germinação, emergência de plântulas em areia, índice de velocidade de emergência, comprimento total, de parte aérea e raiz de plântulas. Nos diferentes volumes de calda, as sementes de soja de alto vigor apresentam maior qualidade fisiológica em relação às sementes de baixo vigor. $\mathrm{O}$ aumento do volume de calda no tratamento de sementes reduz a qualidade fisiológica das sementes de soja de baixo vigor.
\end{abstract}

Termos para indexação: Glycine max (L.) Merrill, fungicidas, inseticidas, germinação, emergência de plântulas.

\section{Introduction}

Soybean [Glycine $\max (\mathrm{L}$.$) Merrill] stands out as the main$ oleaginous plant cultivated and consumed in the world, due to

\footnotetext{
${ }^{1}$ Submitted on 01/31/2017. Accepted for publication on 03/21/2017. ${ }^{2}$ Departamento de Agronomia, Universidade Estadual de Londrina, Caixa Postal 6001, 86051-990- Londrina, PR, Brasil.
}

its use for human and animal diet and the production of biofuel (Hirakuri and Lazzarotto, 2014). However, productivity increases are still necessary and possible, through practices such the use of high quality seeds (Mertz et al., 2009; Moterle et al., 2011).
${ }^{3}$ Embrapa Soja, Caixa Postal 231, 86001-970 - Londrina, PR, Brasil. *Corresponding author $<$ cristian_brzezinski@yahoo.com.br $>$ 
High quality seeds must present proper sanitary, physical, genetic and physiological characteristics, such as high germination and vigor rates (Zorato and Henning, 2001; França-Neto et al., 2010; Marcos-Filho, 2015). Within the physiological attributes, seed vigor plays a relevant role in the agricultural production, since more vigorous seeds provide quick and even germination, helping the growth of the shoot and the root system, providing plants better development conditions (Bennett, 2001; Carvalho and Nakagawa, 2012).

Improper edaphoclimatic conditions may affect germination and seedling emergence and they may also damage the initial development of the culture. Thus, treating soybean seeds becomes an essential practice to assure the proper stand, by controlling diseases during the initial period of the cultivation, as well as reducing the possibility of penetrating pathogens in intact areas (Balardin et al., 2011; Pereira et al., 2011).

The chemical seed treatment was commonly performed during pre-sowing, both in the farmer's property and the resale itself, with the help of specific machines. However, with the technological advance of agriculture, seed producing companies have been adopting techniques that may maximize the culture yield, such as the industrial seed treatment process (IST), where seeds are treated in the processing line itself and, after that, they are bagged and stored until sowing. This treatment strategy, associated with the use of more effective and precise equipments and techniques, as well as enabling the use of new formulas, containing fungicides, insecticides, nematicides, polymers, micronutrients, biostimulants and inoculum in the same treatment (Brzezinski et al., 2015).

The association of various products in the industrial treatment may result in higher spray volumes than the ones used in the traditional treatment. Thus, exploring studies indicate the possibility of using higher spray volumes without the occurrence of negative effects on the physiological performance of seeds (Krzyzanowski et al., 2007). Segalin et al. (2013) verified that treating soybean seeds with spray volumes up to $1400 \mathrm{~mL} . \mathrm{kg}^{-1}$ did not cause reductions in the physiological quality.

Associated to this, the use of seeds with different vigor levels may also influence the spray volume quantity to be used. According to Carvalho and Nakagawa (2012), the response to a treatment with fungicide depends on the seed vigor. Higher vigor seeds present favorable responses to chemical treatments, whereas medium vigor seeds respond up to a certain extent and the ones with lower vigor practically do not respond. Gomes et al. (2009) verified that lower vigor soybean seeds treated with the fungicide fludioxonil presented less response in relation to higher vigor seeds.

The use of greater spray volumes in the IST, with no consequences for the physiological performance, depends on various factors, among which there is seed vigor. Thus, the goal of this work was to evaluate the effect of different spray volumes, via industrial treatment, over the physiological quality of soybean seeds with different vigor levels.

\section{Material and Methods}

The test was conducted at Embrapa in Núcleo Tecnológico de Sementes e Grãos of the Empresa Brasileira de Pesquisa Agropecuária, in Londrina, Paraná state, at the Laboratórios de Fisiologia e Tecnologia de Sementes. The cultivars BRS 360 RR and BRS 1010 IPRO were used; they were analyzed separately.

The experimental design was completely randomized, in a $2 \times 5$ factor scheme, with four replications. Factors consisted in seeds with two vigor levels (high and low) and five spray volumes $\left(0,600,1200,1800\right.$ and $\left.2400 \mathrm{~mL} .100 \mathrm{~kg}^{-1}\right)$.

Seeds that were classified as low vigor ones were obtained from high vigor seed lots, through the application of the accelerated aging technique. In order to conduct the aging, seeds were placed in gerbox ${ }^{\circledR}$ type crystal polystyrene boxes, with canvas supports, containing $40 \mathrm{~mL}$ of distillated water. After that, they were placed in a Water-jacketed incubation chamber, at the temperature of $41^{\circ} \mathrm{C}$ for 48 hours, thus causing reduction in their vigor. Seeds that were not submitted to accelerated aging were considered high vigor ones and aged seeds were considered low vigor ones.

In order to characterize the seed lots according to the vigor, the physiological quality of seeds was determined by the following tests (Table 1): Germination and germination first count - performed according to the Rules for Seed Testing (Brasil, 2009); Total length of seedling shoot and roots according to the methodology proposed by Nakagawa (1999); Dry matter mass of shoot and roots - performed according to Nakagawa (1999); Seedling emergence speed index - conducted under greenhouse conditions, using the equation suggested by Maguire (1962); Seedling emergence in sand - referring to the total count of seedlings emerged 12 days after sowing.

In order to obtain different spray volumes, the maximum volume to be used was initially determined and, starting from it, the other volumes were obtained by decreasing doses of inoculum, biostimulants, polymers and micronutrients (Table 2). The used products were: F: fungicide carbendazim + thiram (Derosal Plus $\left.^{\circledR}\right)$; I: insecticide imidacloprid + tiodicarbe $\left(\right.$ Cropstar $\left.^{\circledR}\right)$; $\mathrm{N}$ : nematicide amabectin $\left(\right.$ Abamectin $\left.^{\circledR}\right)$; M: micronutrients cobalt, molybdenum and zinc (Broadacre $\mathrm{CMZ}^{\circledR}$ ); P: polymer $\left(\right.$ Peridiam $\left.^{\circledR}\right)$; B: biostimulant kinetin + gibberellic acid, such as GA3 + 4-indole-3-butryc acid (Stimulate ${ }^{\circledR}$ ) and IN: Inoculum Bradyrhizobium japonicum (Gelfix $5^{\circledR}$ ). 
Table 1. Average values of physiological quality attributes of soybean seeds, in order to characterize lots with high vigor (HV) and low vigor (LV).

\begin{tabular}{|c|c|c|c|c|c|c|c|c|c|c|}
\hline \multirow{2}{*}{ Cultivar } & \multicolumn{2}{|c|}{ FCG } & \multicolumn{2}{|c|}{$\mathrm{G}$} & \multicolumn{2}{|c|}{ TSL } & \multicolumn{2}{|c|}{ LAP } & \multicolumn{2}{|c|}{ RL } \\
\hline & $\mathrm{HV}$ & LV & $\mathrm{HV}$ & LV & $\mathrm{HV}$ & LV & $\mathrm{HV}$ & LV & $\mathrm{HV}$ & LV \\
\hline BRS 360 RR & 93 & 85 & 96 & 92 & 25.08 & 19.52 & 9.50 & 8.69 & 15.58 & 10.83 \\
\hline BRS 1010 IPRO & 89 & 78 & 93 & 86 & 24.35 & 18.70 & 8.50 & 7.33 & 15.85 & 11.37 \\
\hline \multirow{2}{*}{ Cultivar } & \multicolumn{3}{|c|}{ DMAP } & \multicolumn{3}{|c|}{ RDM } & \multicolumn{2}{|c|}{ ESI } & \multicolumn{2}{|c|}{ SE } \\
\hline & & & LV & & & LV & $\mathrm{HV}$ & LV & $\mathrm{HV}$ & LV \\
\hline BRS 360 RR & & & 1.61 & & & 0.48 & 25.74 & 19.03 & 98 & 86 \\
\hline BRS 1010 IPRO & & & 1.24 & & & 0.59 & 24.22 & 18.87 & 97 & 86 \\
\hline
\end{tabular}

FCG: First count of germination (\%); G: Germination (\%); TSL: Total seedling length (cm); LAP: Shoot length (cm), RL: Root length (cm); DMAP: Dry matter of the shoot (mg per seedling); RDM: Root dry matter (mg per seedling); ESI: Emergence speed index and SE: Seedling emergence in sand (\%).

Table 2. Products and doses used in the industrial treatment of soybean seeds to obtain different spray volumes $\left(\mathrm{mL} .100 \mathrm{~kg}^{-1}\right)$.

\begin{tabular}{ccccccccc}
\hline Volumes & $\mathrm{F}^{1}$ & $\mathrm{I}$ & $\mathrm{N}$ & $\mathrm{M}$ & $\mathrm{P}$ & $\mathrm{B}$ & $\mathrm{IN}$ & Total \\
\hline 0 (control sample) & - & - & - & - & - & - & - & - \\
600 & $200^{2}$ & 300 & 100 & - & - & - & - & - \\
1200 & 200 & 300 & 100 & 400 & 200 & - & - & 1200 \\
1800 & 200 & 300 & 100 & 400 & 200 & 600 & -200 \\
2400 & 200 & 300 & 100 & 400 & 200 & 800 & 400 & 2400 \\
\hline
\end{tabular}

${ }^{1}$ Product type: F: fungicide (carbendazim + thiram); I: insecticide (imidacloprid + tiodicarbe); N: nematicide (amabectin); M: micronutrients (cobalt, molybdenum and zinc); P: polymer (peridiam); B: biostimulant (kinetin + gibberellic acid, such as GA3 + 4-indole-3-butryc acid) and IN: Inoculum (Bradyrhizobium japonicum). ${ }^{2}$ Commercial product dose: $\mathrm{mL} .100 \mathrm{~kg}^{-1}$ of seeds.

Seed treatment was performed using a Batch Modular Coater (BMC) machine, which simulates the industrial treatment of seeds in lower quantities.

In order to determine the physiological the following evaluations were performed:

Germination: performed with four subsamples of 50 seeds per replication, totalizing 800 seeds per treatment. Seeds were positioned on paper towel rolls and moistened in the proportion of 2.5 times the dry paper mass in water. After this, rolls were taken to a germinator at the temperature of $25{ }^{\circ} \mathrm{C}$. Evaluations were performed 8 days after seeding, according to the Rules for Seed Testing (Brasil, 2009), counting the normal seedlings, and the results were expressed in percentage.

First count of the germination test: performed together with the germination test. The evaluation was performed five days after seeding, counting only the normal seedlings, with results expressed in percentage (Brasil, 2009).

Seedling emergence in sand: performed with 800 seeds per treatment, divided into two subsamples of 100 seeds per each replication. Sowing was made in plastic trays containing sand. The test was conducted under greenhouse conditions (Van der Hoeven ${ }^{\circledR}$ model) and the substrate moisture was maintained with irrigations, according to the seedlings' need. The final evaluation on the number of normal emerged seedlings was performed in the twelfth day, and the results were expressed in percentage.
Seedling emergence speed index: performed together with the seedling emergence test in sand. Evaluations were performed daily, starting from the beginning of emergence, recording the number of emerged seedlings until the twelfth day after sowing. In order to calculate the emergence speed index (ESI) the equation suggested by Maguire (1962) was used: $E S I=N_{1} / D_{1}+N_{2} / D_{2}+N_{n} / D_{n}$, where $N_{1}=$ number of seedlings emerged on the first day; $\mathrm{N}_{\mathrm{n}}$ = accumulated number of emerged seedlings; $D_{1}=$ first count day; $D_{n}=$ number of days counted after sowing.

Total length of the seedlings shoot and root: five subsamples of 20 seeds each were used per replication, totalizing 400 seeds per treatment. Seeds were distributed on paper towel rolls and dampened with distilled water in the proportion of 2.5 times the dry paper mass, and kept in a germinator at $25{ }^{\circ} \mathrm{C}$ for five days (Nakagawa, 1999). Subsequently, the total length of the shoot and of the primary root of the seedlings was determined with the help of a millimeter ruler, and the results were expressed in $\mathrm{cm}$.

The obtained data were analyzed in terms of normality and homoscedasticity using the Shapiro-Wilk and the Hartley tests respectively, which indicated no need for transformation. The analysis of variance was performed and averages were compared by Tukey's test at 5\% probability. Analyses were executed by the computer program SISVAR - System for Analysis of Variance program (Ferreira, 2011). 


\section{Results and Discussion}

For all variables there was an interaction between the factors seed vigor and spray volumes used in the IST. For the germination test, in both cultivars, the use of high vigor seeds provided higher percentages in relation to low vigor seeds, in all used spray volumes (Table 3). This response is due to the difference in the deterioration stage of seeds with different vigor levels. According to Marcos-Filho (2015), deterioration is a process starting from the physiological ripeness; it occurs at a progressive pace and contains a hypothetical sequence, culminating with the death of seeds. Thus, seeds that are at an advanced deterioration stage, such as the low vigor ones, presented a decrease in the transpiration rate and in the synthesis of ATP, as well as alterations in enzymatic systems, protein synthesis and mobilization of stocks, which consequently reduced their germination potential.

Supporting the results obtained for germination, Henning et al. (2010) reported that soybean seeds with higher vigor have a higher capacity to mobilize stocks during the germination process, resulting in seedlings with better initial development.

Another aspect to highlight was the high germination percentage of seeds at the beginning of the test, after its characterization. For the cultivar BRS 360 RR, the percentages were 96 and $92 \%$ and for the cultivar BRS 1010 IPRO were 93 and 86\%, for high and low vigor seeds, respectively (Table 1). According to Martins et al. (2009) in comparative studies among lots with different vigor levels, it is fundamental that both present similar germination and within the commercialization standards, since the deterioration process starts with the reduction of various attributes of seed performance and vigor, resulting in the end in the loss of their germination capacity.

On low vigor seeds, in both cultivars, spray volumes above $600 \mathrm{~mL}$ caused decreases in the germination of seeds. As for high vigor seeds, volumes above $1800 \mathrm{~mL}$ for the cultivar BRS $360 \mathrm{RR}$ and $1200 \mathrm{~mL}$ for the cultivar BRS 1010 IPRO reduced the germination potential (Table 3). For high vigor seeds the decrease according to the increase in spray volumes did not result in germination percentages below $80 \%$, which is the minimum value required for commercialization (MAPA, 2013). Segalin et al. (2013) obtained similar results working with soybean seeds treated with spray volumes up to $1400 \mathrm{~mL} .100 \mathrm{~kg}^{-1}$, classified in sieves with different diameters.

As for low vigor seeds, the accentuated germination decrease may have occurred due to the quick soaking of seeds because of the increase in spray volumes. According to Vieira et al. (2002) high vigor seeds have the capacity to endure greater disorders caused during the soaking process by reorganizing cells and maintaining membrane integrity. On the other hand, in low vigor seeds this behavior is damaged. According to Bewley and Black (1994), deteriorated seeds absorb water more rapidly this is associated to the higher

Table 3. Germination (G), first count of the germination test (FCG), seedling emergence in sand (SE), emergence speed index (ESI) of soybean seeds from the cultivars BRS 360 RR and BRS 1010 IPRO, with two vigor levels [high (HV) and low (LV)], treated industrially with different spray volumes.

\begin{tabular}{|c|c|c|c|c|c|c|c|c|}
\hline \multicolumn{9}{|c|}{---------------- BRS 360 RR ---------------- } \\
\hline \multirow{2}{*}{ Volumes $^{1}$} & \multicolumn{2}{|c|}{$\mathrm{G}(\%)$} & \multicolumn{2}{|c|}{ FCG $(\%)$} & \multicolumn{2}{|c|}{ SE $(\%)$} & \multicolumn{2}{|c|}{ ESI } \\
\hline & $\mathrm{HV}$ & LV & $\mathrm{HV}$ & LV & $\mathrm{HV}$ & LV & HV & LV \\
\hline 0 & $96 \mathrm{Aa}$ & $88 \mathrm{Ab}$ & $94 \mathrm{Aa}$ & $87 \mathrm{Ab}$ & $95 \mathrm{Aa}$ & $84 \mathrm{Ab}$ & $23.74 \mathrm{ABa}$ & $18.02 \mathrm{Ab}$ \\
\hline 600 & $94 \mathrm{Aa}$ & $81 \mathrm{Bb}$ & $89 \mathrm{ABa}$ & $58 \mathrm{Bb}$ & $96 \mathrm{Aa}$ & $58 \mathrm{Ab}$ & $24.68 \mathrm{Aa}$ & $11.23 \mathrm{Bb}$ \\
\hline 1200 & $90 \mathrm{ABa}$ & $57 \mathrm{Cb}$ & $86 \mathrm{BCa}$ & $38 \mathrm{Cb}$ & $95 \mathrm{Aa}$ & $57 \mathrm{Bb}$ & $21.95 \mathrm{BCa}$ & $11.16 \mathrm{Bb}$ \\
\hline 1800 & $88 \mathrm{Ba}$ & $33 \mathrm{Db}$ & $86 \mathrm{BCa}$ & $28 \mathrm{Db}$ & $94 \mathrm{Aa}$ & $49 \mathrm{Bb}$ & $21.80 \mathrm{BCa}$ & $9.07 \mathrm{BCb}$ \\
\hline 2400 & $85 \mathrm{Ba}$ & $20 \mathrm{~Eb}$ & $82 \mathrm{Ca}$ & $20 \mathrm{Db}$ & $93 \mathrm{Aa}$ & $37 \mathrm{Cb}$ & $21.42 \mathrm{Ca}$ & $7.03 \mathrm{Cb}$ \\
\hline C.V $(\%)$ & \multicolumn{2}{|c|}{4.04} & \multicolumn{2}{|c|}{4.43} & \multicolumn{2}{|c|}{7.29} & \multicolumn{2}{|c|}{6.36} \\
\hline \multicolumn{9}{|c|}{--------------- BRS 1010 IPRO --------------- } \\
\hline \multirow{2}{*}{ Volumes $^{1}$} & \multicolumn{2}{|c|}{ G (\%) } & \multicolumn{2}{|c|}{ FCG $(\%)$} & \multicolumn{2}{|c|}{ SE $(\%)$} & \multicolumn{2}{|c|}{ ESI } \\
\hline & $\mathrm{HV}$ & LV & $\mathrm{HV}$ & LV & HV & LV & $\mathrm{HV}$ & LV \\
\hline 0 & $98 \mathrm{Aa}$ & $89 \mathrm{Ab}$ & $96 \mathrm{Aa}$ & $77 \mathrm{Ab}$ & $95 \mathrm{Aa}$ & $83 \mathrm{Ab}$ & $23.22 \mathrm{Aa}$ & $18.72 \mathrm{Ab}$ \\
\hline 600 & $93 \mathrm{Aa}$ & $80 \mathrm{Bb}$ & $89 \mathrm{Aa}$ & $54 \mathrm{Bb}$ & $94 \mathrm{ABa}$ & $56 \mathrm{Bb}$ & $22.77 \mathrm{ABa}$ & $12.81 \mathrm{Bb}$ \\
\hline 1200 & $81 \mathrm{Ba}$ & $60 \mathrm{Cb}$ & $85 \mathrm{Ba}$ & $41 \mathrm{Cb}$ & $94 \mathrm{ABa}$ & $41 \mathrm{Cb}$ & $22.77 \mathrm{ABa}$ & $9.37 \mathrm{Cb}$ \\
\hline 1800 & $83 \mathrm{Ba}$ & $44 \mathrm{Cb}$ & $76 \mathrm{Ba}$ & $31 \mathrm{Db}$ & $93 \mathrm{ABa}$ & $39 \mathrm{Cb}$ & $21.76 \mathrm{BCa}$ & $8.26 \mathrm{Cb}$ \\
\hline 2400 & \multirow{2}{*}{\multicolumn{2}{|c|}{$81 \mathrm{Ba}$}} & $76 \mathrm{Ba}$ & $30 \mathrm{Db}$ & $85 \mathrm{Ba}$ & $37 \mathrm{Cb}$ & $19.56 \mathrm{Ca}$ & $7.96 \mathrm{Cb}$ \\
\hline C.V (\%) & & & \multicolumn{2}{|c|}{8.76} & \multicolumn{2}{|c|}{6.13} & \multicolumn{2}{|c|}{6.93} \\
\hline
\end{tabular}

Averages followed by the same letter, lowercase letter in the line and capital letter in the column, do not differ among themselves by Tukey's test at $5 \%$ probability.

${ }^{1}$ Spray volumes: $\mathrm{mL} .100 \mathrm{~kg}^{-1}$ of seeds. 
permeability of the membranes. The prejudicial effects of seed quick soaking may be the main cause of the decrease in the germination capacity of seeds, since it is the reorganization speed of the membrane system that reflects the vigor of seeds (Tilden and West, 1985).

In works developed by Costa et al. (2002) and Silva and Villela (2011), authors observed that soybean seeds with lower physiological quality presented higher water absorption rates during the first hours of the soaking process. Rossetto et al. (1997) observed that the decrease in the soaking speed of soybean seeds reduced damages caused by soaking.

In the first count of germination test, results referring to the comparison between seed vigor levels supported the ones observed in the germination test (Table 3). According to Schuch et al. (1999), more vigorous seeds presented higher speed in the metabolic processes, providing the quicker and more even emission of the primary root in the germination process, helping the growth rate of seedlings.

As for volumes, in high vigor seeds reductions were observed starting from $1200 \mathrm{~mL} .100 \mathrm{~kg}^{1}$, compared to the control sample (Table 3). In low vigor seeds, reductions were verified from $600 \mathrm{~mL} .100 \mathrm{~kg}^{-1}$, thus inferring that less vigorous seeds are more susceptible to soaking-related damages, event at lower volumes.

In addition to the effects of seed vigor and increase of spray volume over the soaking process, discussed in the germination variable, some authors report that the kind of used vehicle may also influence the soaking process of seeds. Different vehicles for water provide different soaking rates, diminishing or accentuating the risks for damages to the embryonic axis, caused by quick soaking (Farooq et al., 2012; Sediyama et al., 2012; Almeida et al., 2015).

As for the emergence of seedlings in sand, high vigor seeds presented higher percentages in both cultivars (Table 3). Hamman et al. (2002) and Kolchinski et al. (2005) also observed that the use of lots with more vigorous soybean seeds provided greater seedling emergence in comparison with less vigorous lots.

The increase in the spray volumes used for the industrial treatment reduced seedling emergence for low vigor seeds (Table 3); this reduction occurred with $1200 \mathrm{~mL} 100 \mathrm{~kg}^{-1}$ and

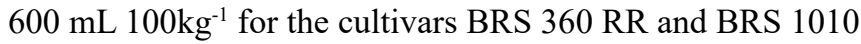
IPRO, respectively. For high vigor seeds from the cultivar BRS 1010 IPRO, differences were observed only between volumes of 0 and $2400 \mathrm{~mL} .100 \mathrm{~kg}^{-1}$.

As for the emergence speed index (ESI), results were similar to the ones observed in the emergence of seedlings for the comparison between vigor levels, in both cultivars (Table 3 ). Thus, high vigor seeds presented higher emergence percentage and speed, producing seedlings with higher competitive ability to capture and use the resources of the mean. In addition to this, Floss (2008) and Panozzo et al. (2009) verified that the seedling emergence anticipation provided a longer period of vegetative growth of the cultures, leading to a higher accumulation of photo-assimilated compounds because of the higher $\mathrm{CO}_{2}$ inflow and, consequently, higher growth rate.

In addition, for ESI there were reductions in the results for low vigor seeds according to the spray volume increase, in both cultivars, which were reducing with the use of $600 \mathrm{~mL}$. $100 \mathrm{~kg}^{-1}$ (Table 3). As for high vigor seeds, volumes above $1200 \mathrm{~mL}$ for the cultivar BRS $360 \mathrm{RR}$ and $1800 \mathrm{~mL}$ for the cultivar BRS 100 IPRO reduced the ESI, respectively.

As for seedling growth, evaluated by the total length test, it was possible to observe greater length in seedlings coming from high vigor seeds, for both cultivars (Table 4). Supporting the results by Vanzolini and Carvalho (2002) and Henning et al. (2010), Kolchinski et al. (2006) also verified that soybean plants coming from more vigorous seeds presented higher growth rates, as well as wider leaf area and dry matter production.

In both cultivars, the increase in the spray volumes applied in low vigor seeds reduced the total length of plants (Table 4). As for high vigor seeds, reductions were observed starting from $1200 \mathrm{~mL} .100 \mathrm{~kg}^{-1}$. Values obtained for the cultivar BRS $360 \mathrm{RR}$ at volumes of 0,600, 1200 and 1800 $\mathrm{mL} .100 \mathrm{~kg}^{-1}$, and for the cultivar BRS 284 at volumes of 0 and $600 \mathrm{~mL} .100 \mathrm{~kg}^{-1}$, demonstrated that the average total length was higher than $27.0 \mathrm{~cm}$; this value was used by Vanzolini and Carvalho (2002) to classify soybean seeds as more vigorous.

As for the shoot length, high vigor seeds presented higher values in both cultivars (Table 4). For low vigor seeds from the cultivar BRS $360 \mathrm{RR}$, the spray volume increase provided reduction in the shoot length of soybean seedlings with 600 mL. $100 \mathrm{~kg}^{-1}$ (Table 4). For the cultivar BRS 1010 IPRO, reductions in the shoot length were observed starting from $1800 \mathrm{~mL} .100 \mathrm{~kg}^{-1}$.

High vigor seeds from the cultivar BRS 360 RR presented lower shoot length starting from $1200 \mathrm{~mL} .100 \mathrm{~kg}^{-1}$, whereas for the cultivar BRS 1010 IPRO reductions were observed with volumes of $2400 \mathrm{~mL} .100 \mathrm{~kg}^{-1}$.

As for root length, in both cultivars, seedlings coming from high vigor seeds presented greater root growth in relation to low vigor seeds (Table 4).

In both cultivars, for low vigor seeds, there was a decrease in the root length with the increase in spray volumes (Table 4). As for high vigor seeds from the cultivars BRS $360 \mathrm{RR}$ and BRS 1010 IPRO, reductions were observed starting from 1800 and $1200 \mathrm{~mL} .100 \mathrm{~kg}^{-1}$, respectively. 
Table 4. Total seedling length (TSL), shoot length (LAP) and root length (RL) of soybean seeds from the cultivars BRS 360 RR and BRS 1010 IPRO, with two vigor levels [high (HV) and low (LV)], treated industrially with different spray volumes.

\begin{tabular}{|c|c|c|c|c|c|c|}
\hline \multicolumn{7}{|c|}{--------------- BRS 360 RR ------------- } \\
\hline \multirow{2}{*}{ Volumes $^{1}$} & \multicolumn{2}{|c|}{ TSL (cm) } & \multicolumn{2}{|c|}{ LAP $(\mathrm{cm})$} & \multicolumn{2}{|c|}{$\mathrm{RL}(\mathrm{cm})$} \\
\hline & $\mathrm{HV}$ & LV & $\mathrm{HV}$ & LV & $\mathrm{HV}$ & LV \\
\hline 0 & $30.02 \mathrm{Aa}$ & $19.12 \mathrm{Ab}$ & $10.62 \mathrm{Aa}$ & $9.47 \mathrm{Ab}$ & $18.50 \mathrm{Aa}$ & $9.37 \mathrm{Ab}$ \\
\hline 600 & $28.70 \mathrm{ABa}$ & $15.22 \mathrm{Bb}$ & $9.77 \mathrm{ABa}$ & $8.45 \mathrm{Bb}$ & $19.40 \mathrm{Aa}$ & $6.80 \mathrm{Bb}$ \\
\hline 1200 & $28.12 \mathrm{BCa}$ & $12.22 \mathrm{Cb}$ & $9.60 \mathrm{Ba}$ & $7.60 \mathrm{Bb}$ & $17.57 \mathrm{ABa}$ & $4.65 \mathrm{Cb}$ \\
\hline 1800 & $27.17 \mathrm{BCa}$ & $9.17 \mathrm{Db}$ & $9.22 \mathrm{Ba}$ & $5.17 \mathrm{Cb}$ & $15.60 \mathrm{BCa}$ & $4.42 \mathrm{Cb}$ \\
\hline 2400 & $23.20 \mathrm{CDa}$ & $9.32 \mathrm{Db}$ & $8.60 \mathrm{Ba}$ & $4.70 \mathrm{Cb}$ & $14.65 \mathrm{Ca}$ & $3.72 \mathrm{Cb}$ \\
\hline C.V $(\%)$ & \multicolumn{2}{|c|}{5.57} & \multicolumn{2}{|c|}{6.97} & \multicolumn{2}{|c|}{8.03} \\
\hline \multicolumn{7}{|c|}{------------ BRS 1010 IPRO -------------- } \\
\hline \multirow{2}{*}{ Volumes $^{1}$} & \multicolumn{2}{|c|}{ TSL $(\mathrm{cm})$} & \multicolumn{2}{|c|}{ LAP $(\mathrm{cm})$} & \multicolumn{2}{|c|}{$\mathrm{RL}(\mathrm{cm})$} \\
\hline & $\mathrm{HV}$ & LV & $\mathrm{HV}$ & LV & $\mathrm{HV}$ & LV \\
\hline 0 & $24.82 \mathrm{Aa}$ & $19.55 \mathrm{Ab}$ & $7.52 \mathrm{Aa}$ & $6.55 \mathrm{Ab}$ & $18.30 \mathrm{Aa}$ & $12.02 \mathrm{Ab}$ \\
\hline 600 & $26.12 \mathrm{Aa}$ & $11.97 \mathrm{Bb}$ & $7.85 \mathrm{Aa}$ & $6.50 \mathrm{Ab}$ & $18.27 \mathrm{Aa}$ & $5.37 \mathrm{Bb}$ \\
\hline 1200 & $20.92 \mathrm{Ba}$ & $11.05 \mathrm{Bb}$ & $6.60 \mathrm{Aa}$ & $6.12 \mathrm{Ab}$ & $14.40 \mathrm{Ba}$ & $4.99 \mathrm{BCb}$ \\
\hline 1800 & $18.07 \mathrm{Ca}$ & $9.52 \mathrm{BCb}$ & $6.40 \mathrm{Aa}$ & $5.37 \mathrm{Bb}$ & $11.47 \mathrm{Ca}$ & $4.17 \mathrm{Cb}$ \\
\hline 2400 & $12.32 \mathrm{Da}$ & $7.30 \mathrm{Cb}$ & $5.07 \mathrm{Ba}$ & $4.20 \mathrm{Cb}$ & $7.25 \mathrm{Da}$ & $2.77 \mathrm{Db}$ \\
\hline C.V $(\%)$ & \multicolumn{2}{|c|}{8.53} & \multicolumn{2}{|c|}{10.70} & \multicolumn{2}{|c|}{9.11} \\
\hline
\end{tabular}

Averages followed by the same letter, lowercase letter in the line and capital letter in the column, do not differ among themselves by Tukey's test at $5 \%$ probability.

${ }^{1}$ Spray volumes: $\mathrm{mL} .100 \mathrm{~kg}^{-1}$ of seeds.

The results observed in the seedling growth demonstrated that the shoot length test presented lower responses in relation to spray volumes and vigor levels of seeds (Table 4). Thus, the root length test (Table 4), appeared to be the most suitable parameter to differentiate lots with differences in seed vigor, as reported by Schuch et al. (1999) and Vanzolini et al. (2007).

The higher sensitivity of the root length test may be related to the structure of soybean seeds and to the germination process, since soybean seeds have, within their external structures, the micropyle-hilum area. According to Peske and Peske (2011), this area generally has higher permeability to water, and it is responsible for approximately $20 \%$ of its flow during the first 24 hours of seed hydration. Thus, after applying the spray volumes on seeds, part of them is deposited and absorbed by the micropyle-hilum area. Thus, along the germination process, the radicle is the first structure of the embryo that develops and the first to be touched by the chemical product; phytotoxicity may occur, reducing the length of roots.

The tested cultivars responded similarly to the vigor levels of seeds and to treatments with different spray volumes. Thus, it becomes essential to use lots of high vigor soybean seeds in the industrial treatment, due to the attenuation effect that the chemical treatment causes over low vigor seeds, reducing their quality in an accentuated way as spray volumes increase.

\section{Conclusions}

At different spray volumes, high vigor soybean seeds present higher physiological quality in relation to low vigor seeds.

The increase in the spray volume while treating seeds reduces the physiological quality of low vigor soybean seeds.

\section{Acknowledgments}

To the Coordenação de Aperfeiçoamento de Pessoal de Nível Superior - CAPES, for granting the scholarship to the first author. To the Universidade Estadual de Londrina and the Empresa Brasileira de Pesquisa Agropecuária (Embrapa Soja) for the structure and the financial support to develop this work.

\section{References}

ALMEIDA, L.G.; BRANDÃO, A.S.; ROSSETTO, C.A.V. Embebição e qualidade fisiológica de sementes de tremoço branco tratadas com micronutrientes. Ciência Rural, v.45, n.4, p.612-618, 2015. http:// www.scielo.br/pdf/cr/v45n4/0103-8478-cr-00-00-cr20130660.pdf 
BALARDIN, R.S.; SILVA, F.L.; DEBONA, D.; CORTE, G.D.; FAVERA, D.D.; TORMEN, N.R. Tratamento de sementes com fungicidas e inseticidas como redutores dos efeitos do estresse hídrico em plantas de soja. Ciência Rural, v.41, n.7, p.1120-1126, 2011. http://www.scielo.br/scielo.php?script=sci arttext\&pid=S0103-84782011000700002

BEWLEY, J.D.; BLACK, M. Seeds: physiology of development and germination. 2ed. New York: Plenum Press, 1994. 445p.

BENNETT, M.A. Determination and standardization challenges of vigor tests of vegetable seeds. Informativo Abrates, v.11, n.3, p.5862, 2001. http://www.bdpa.cnptia.embrapa.br/busca?b=ad\&biblioteca=vazio\&busca=autoria:\%22BENNETT,\%20M.\%20A.\%22

BRASIL. Ministério da Agricultura, Pecuária e Abastecimento. Regras para análise de sementes. Ministério da Agricultura, Pecuária e Abastecimento. Secretaria de Defesa Agropecuária. Brasília: MAPA/ACS, 2009. 395p. http://www.agricultura.gov.br/arq_editor/ file/2946_regras_analise_sementes.pdf

BRZEZINSKI, C.R.; HENNING, A.A.; ABATI, J.; HENNING, F.A.; FRANÇA-NETO, J.B.; KRZYZANOWSKI, F.C.; ZUCARELI, C. Seeds treatment times in the establishment and yield performance of soybean crops. Journal of Seed Science, v.37, n.2, p.147-153, 2015. http://www. scielo.br/scielo.php?pid=S2317-15372015000200147\&script=sci_arttext

CARVALHO, N.M.; NAKAGAWA, J. Sementes: ciência, tecnologia e produção. Jaboticabal: FUNEP, 2012. 590p.

COSTA, J.A.; PIRES, J.L.F.; THOMAS, A.L.; ALBERTON, M. Variedades de soja diferem na velocidade e capacidade de absorver água. Scientia Agraria, v.3, n.1, p.91-96, 2002. http://ojs.c3sl.ufpr. br/ojs/index.php/agraria/article/view/1036

FAROOQ, M.; WAHID, A.; KADAMBOT, H.M.S. Micronutrient application through seed treatments a review. Journal of Soil Science and Plant Nutrition, v.12, n.1, p.125-142, 2012. http://www.scielo. cl/scielo.php?script=sci arttext\&pid=S0718-95162012000100011

FERREIRA, D.F. Sisvar: A computer statistical analysis system. Ciência e Agrotecnologia, v.35, n.6, p.1039-1042, 2011. http:// www.scielo.br/pdf/cagro/v35n6/a01v35n6.pdf

FLOSS, E.L. Fisiologia das plantas cultivadas. Passo Fundo-RS: UPF, 4ed. 749p. 2008.

FRANÇA-NETO, J.B.; KRZYZANOWSKI, F.C.; HENNING, A.A. A importância do uso de sementes de soja de alta qualidade. Informativo Abrates, v.20, n.1, p.37-38, 2010. http://www.abrates. org.br/images/stories/informativos/v20n12/artigo04.pdf

GOMES, D.P.; BARROZO, L.M.; SOUZA, A.L.; SADER, R.; SILVA, G.C. Efeito do vigor e do tratamento fungicida nos testes de germinação e de sanidade de sementes de soja. Bioscience Journal, v.25, n.6, p.59-65, 2009. http://www.seer.ufu.br/index.php/ biosciencejournal/article/view/7010

HAMMAN, B.; EGLI, D.B.; KONING, G. Seed vigor, soil borne pathogens, pre emergent growth, and soybean seedling emergence. Crop Science, v.42, p.451-457, 2002. https:/www.researchgate.net/ publication/237591653_Seed_Vigor_Soilborne_Pathogens_ Preemergent_Growth_and_Soybean_Seedling_Emergence
HENNING, F.A.; MERTZ, L.M.; JACOB JUNIOR, E.A.; MACHADO, R.D.; FISS, G.; ZIMMER, P.D. Composição química e mobilização de reservas em sementes de soja de alto e baixo vigor. Bragantia, v.69, n.3, p.727-734, 2010. http://www.scielo.br/pdf/ brag/v69n3/26.pdf

HIRAKURI, M.H.; LAZZAROTTO, J.J. O agronegócio da soja nos contextos mundial e brasileiro. Londrina: Embrapa Soja, 2014. 70p. (Documentos 349).

KOLCHINSKI, E.M.; SCHUCH, L.O.B.; PESKE, S.T. Vigor de sementes e competição intra-específica em soja. Ciência Rural, v.35, n.6, p.1248-1256, 2005. http://www.scielo.br/scielo.php?pid=S0103$84782005000600004 \&$ script $=$ sci_arttext

KOLCHINSKI, E.M.; SCHUCH, L.O.B.; PESKE, S.T. Crescimento inicial de soja em função do vigor das sementes. Revista Brasileira de Agrociência, v.12, n.2, p.163-166, 2006. https://periodicos.ufpel. edu.br/ojs2/index.php/CAST/article/view/4513

KRZYZANOWSKI, F.C.; HENNING, A.A.; FRANÇA-NETO, J.B.; LOPES, I.O.N.; ZORITA, M.D.; COSTA, N.P. Volume de calda com diferentes produtos para o tratamento de semente de soja e seu efeito sobre a qualidade fisiológica. Londrina: Embrapa Soja, 2007. 48p. (Documentos, 290).

MAGUIRE, J. D. Speed of germination-aid in selection and evaluation for seedling emergence and vigor. Crop Science, v.2, n.1, p.176-177, 1962. https://dl.sciencesocieties.org/publications/cs/ abstracts/2/2/CS0020020176

MAPA. Ministério da Agricultura, Pecuária e Abastecimento. Instrução Normativa $\mathrm{N}^{\circ} 45$, de 17 de setembro de 2013. Anexo XXIII - Padrões para produção e comercialização de sementes de soja. http://apasem.com.br/site/wpcontent/uploads/padroesin0452013.pdf Accessed on: Nov 27 $7^{\text {th }}, 2015$.

MARCOS-FILHO, J. Fisiologia de sementes de plantas cultivadas. Londrina: ABRATES, 2015. 660p.

MARTINS, C.C.; NAKAGAWA, J.; BOVI, M.L.A. Avaliação da qualidade fisiológica de sementes de açaí. Revista Brasileira de Fruticultura, v.31, n.1, p.231-235, 2009. http://www.scielo.br/scielo. php?script=sci_arttext\&pid=S0100-29452009000100032

MERTZ, L.M.; HENNING, F.A.; ZIMMER, P.D. Bioprotetores e fungicidas químicos no tratamento de sementes de soja. Ciência Rural, v.39, n.1, p.13-18, 2009. http://www.scielo.br/scielo. php?script=sci_arttext\&pid=S0103-84782009000100003

MOTERLE, L.M.; SANTOS, R.F.; SCAPIM, C.A.; BRACCINI, A.D.L.; BONATO, C.M.; CONRADO, T. Efeito de biorregulador na germinação e no vigor de sementes de soja. Revista Ceres, v.58, n.5, p.651-660, 2011. http://www.scielo.br/scielo.php?pid=S0034737X2011000500017\&script $=$ sci_abstract\&tlng=pt

NAKAGAWA, J. Teste de vigor baseados no desempenho das plântulas. In: KRZYZANOWSKI, F.C.; VIEIRA, R.D.; FRANÇANETO, J.B. (Ed.) Vigor de sementes: conceitos e testes. Londrina: ABRATES, 1999. p.2.1-2.24. 
PANOZZO, L.E.; SCHUCH, L.O.B.; PESKE, S.T.; MIELEZRSKI, F.; PESKE, F.B. Comportamento de plantas de soja originadas de sementes de diferentes níveis de qualidade fisiológica. Revista da Faculdade de Zootecnia, Veterinária e Agronomia, v.16, n.1, p.32-41, 2009. http:// revistaseletronicas.pucrs.br/ojs/index.php/fzva/article/view/4898

PEREIRA, C.E.; OLIVEIRA, J.A.; GUIMARÃES, R.M.; VIEIRA, A.R.; EVANGELISTA, J.R.E.; OLIVEIRA, G.E. Tratamento fungicidae peliculização de sementes de soja submetidas ao armazenamento. Ciência e Agrotecnologia, v.35, n.1, p.158-164, 2011. http://www.scielo.br/ scielo.php?script=sci_arttext\&pid=S1413-70542011000100020

PESKE, S.T.; PESKE, F.B. Absorção de água sob estresse. Seed News, ano XV, n.3, 2011. http://www.seednews.inf.br/html/site/ content/reportagem_capa/imprimir.php?id $=99$

ROSSETTO, C.A.V.; NOVEMBRE, A.D.L.C.; MARCOSFILHO, J.; NAKAGAWA, J. Efeito da disponibilidade hídrica do substrato, da qualidade fisiológica e do teor de água inicial das sementes de soja no processo de germinação. Scientia Agricola, v.54, n.1/2, p.97-105, 1997. http://www.scielo.br/scielo. php?script $=$ sci_arttext\&pid=S0103-90161997000100014

SEDIYAMA, C.A.Z.; REIS, M.S.; SEDIYAMA, C.S.; DIAS, M.A.; SEDIYAMA, T.; DIAS, D.C.F.S. Physiological quality of soybean seed cultivars by osmoconditioning. Comunicata Scientiae, v.3, n.2, p.90-97, 2012. http://dialnet.unirioja.es/servlet/ articulo? codigo $=3959470$

SEGALIN, S.R.; BARBIERI, A.P.P.; HUTH, C.; BECHE, M.; MATTIONI, N.M.; MERTZ, L.M. Physiological quality of soybean seeds treated with different spray volumes. Journal of Seed Science, v.35, n.4, p.501-509, 2013. http://www.scielo.br/scielo. php?pid=S2317-15372013000400012\&script=sci_arttext

SILVA, K.R.G.; VILLELA, F.A. Pré-hidratação e avaliação do potencial fisiológico de sementes de soja. Revista Brasileira de Sementes, v.33, n.2, p.331-345, 2011. http://www.scielo.br/scielo. php?pid=S0101-31222011000200016\&script=sci_arttext
SCHUCH, L.O.B.; NEDEL, J.L.; ASSIS, F.N. Crescimento em laboratório de plântulas de aveia-preta (Avena strigosa Schreb.) em função do vigor das sementes. Revista Brasileira de Sementes, v.21, n.1, p.229-234, 1999. http://www.abrates.org.br/revista/artigos/1999/ v21n1/artigo34.pdf

TILDEN, R.L.; WEST, S.H. Reversal of the effects of ageing in soybean seeds. Plant Physiology, v.77, n.3, p.584-586, 1985. http:// www.ncbi.nlm.nih.gov/pmc/articles/PMC1064568/

VANZOLINI, S.; CARVALHO, N.M. Efeito do vigor de sementes de soja sobre o seu desempenho em campo. Revista Brasileira de Sementes, v.24, n.1, p.33-41, 2002. http://www.scielo.br/scielo. php?script=sci_arttext\&pid=S0101-31222002000100006

VANZOLINI, S.; ARAKI, C.A.S.; SILVA, A.C.T.M.; NAKAGAWA, J. Teste de comprimento de plântula na avaliação da qualidade fisiológica de sementes de soja. Revista Brasileira de Sementes, v. 29, n. 2, p. 90-96, 2007. http://www.scielo.br/scielo.php?script=sci arttext\&pid=S010131222007000200012\&lng=pt\&nrm=iso\&tlng=pt

VIEIRA, R.D.; PENARIOL, A.L.; PERECIN, D.; PANOBIANCO, M. Condutividade elétrica e o teor de água inicial das sementes de soja. Pesquisa Agropecuária Brasileira, v.37, n.19, p.1333-1338, 2002. http://www.scielo.br/pdf/pab/v37n9/13209.pdf

ZORATO, M.F.; HENNING, A.A. Influência de tratamentos fungicidas antecipados, aplicados em diferentes épocas de armazenamento, sobre a qualidade de sementes de soja. Revista Brasileira de Sementes, v.23, n.2, p.236-244, 2001. http://www. abrates.org.br/revista/artigos/2001/v23n2/artigo33.pdf 